\title{
Actinomycetes: Isolation, Characterization and Screening for Antimicrobial Activity from Different Sites of Chitwan, Nepal
}

\author{
Kamal Rai ${ }^{1,}$, Sujan Khadka ${ }^{2}$, Bidya Shrestha ${ }^{3}$ \\ ${ }^{1}$ Department of Biological Protein Materials, Qingdao Institute of Bioenergy and Bioprocess Technology, Chinese Academy of Sciences, \\ Qingdao, P. R. China \\ ${ }^{2}$ Department of Life Sciences, Biochemistry and Molecular Biology, Central China Normal University, Wuhan, P. R. China \\ ${ }^{3}$ Department of Microbiology, Tri-Chandra Multiple Campus, Tribhuvan University, Kathmandu, Nepal
}

Email address:

raikasam11@gmail.com(K. Rai), sukha11@mails.ccnu.edu.cn(S.Khadka),bidyashr@gmail.com(B. Shrestha)

${ }^{*}$ Corresponding author

\section{To cite this article:}

Kamal Rai, Sujan Khadka, Bidya Shrestha. Actinomycetes: Isolation, Characterization and Screening for Antimicrobial Activity from Different Sites of Chitwan, Nepal. International Journal of Microbiology and Biotechnology. Vol. 3, No. 1, 2018, pp. 25-30.

doi: $10.11648 /$ j.ijmb.20180301.14

Received: January 17, 2018; Accepted: March 19, 2018; Published: April 10, 2018

\begin{abstract}
With the objective to isolate, identify and determine the antimicrobial activity of the soil actinomycetes, this study was done in the laboratory of Nepal Polytechnic Institute, Chitwan (September 2015- April 2016). A total of 30 soil samples were randomly collected and processed from forest, garden, cultivated lands and river side (Narayani and Rapti River) of Chitwan, Nepal. Isolates were identified by colony characterizations, microscopy and biochemical tests. Primary and secondary screening for antibiotic producers was done by single line cross streak and agar cup assay respectively against test organisms, S. Typhi, S. aureus and E. coli. Altogether 25 different actinomycetes from two genera viz; Streptomyces (n=15) and Micromonospora $(\mathrm{n}=10)$ were identified from selected sites $(\mathrm{n}=10$; river side, $\mathrm{n}=5$ each from garden, cultivated and forest soil). Primary screening of $n=12$ isolates was done by inhibition to at least one test bacterium. Of them only $n=9$ ( $n=6$ Streptomyces spp., $\mathrm{n}=3$ Micromonospora spp.) isolates showed promising antibacterial activity (zone of inhibition above $8 \mathrm{~mm}$ ) on secondary screening. Maximum zone of inhibition was $14 \mathrm{~mm}$ observed against $S$. aureus and whereas $18 \mathrm{~mm}$ against $E$. coli and $S$. Typhi respectively. This finding indicates potent antibiotic producer actinomycetes were isolated from soil of Chitwan, study furthering strain selection and identification would pave the way for commercial antibiotic production.
\end{abstract}

Keywords: Actinomycetes, Chitwan, Antibacterial

\section{Introduction}

Climatic and topographical diversity in Nepal has undeniably gifted to multiple biological diversity including micro-organisms. Such microbial multiplicity is always a motivation for the scientific community to investigate for the tremendous microbial potency [1] and of all; microbes producing antibiotics are emphasized most, as antimicrobials are used for infectious diseases treatment.

Genera from actinomycetes remain at the top of the natural antibiotic producers [2]. These microbes are unique genetically comprises high $\mathrm{G}+\mathrm{C}$ content $(>55 \%)$ in their DNA and for their phenotypic characters resembling both bacteria and fungi. More than $70 \%$ of total naturally obtained antibiotics are attributed by two genera viz; Streptomyces and Micromonospora from this group [3, 4, 5]. New strains from this genera have been reported from various ecological sites with varied antimicrobial potency generates hope for findings newer strains from unexplored sites $[6,-9]$. Thus, the search for noble antibiotic producers is still ongoing.

Actinomycetes isolation and their antimicrobial potency have been explored from different parts of globe, both from land and marine soils. Isolates reported from different locality/sites with varied inhibitory effect to the pathogens vehemently supports hope for finding novel antibiotic producer strains with promising inhibitory effect that could help fight growing antimicrobial resistance [1, 6-11]. 
Actinomycetes isolation seems to be predominantly done from normal land soil. Isolates divulged their potency to inhibit normal as well as multidrug resistant pathogens [1214]. These studies have reported various percentages of isolates having potent inhibitory impact against pathogens, however among the different genera from actinomycetes, Streptomyces and Micromonospora were reported to be predominant $[8,9]$. Metabolites at different concentrations secreted by the actinomycetes isolates from different land soils are reported to inhibit different pathogens [6-9].

Several studies on actinomycetes isolation from the marine environment have been reported with varied antimicrobial potency against pathogens as well $[6,7]$. Researchers have reported few to all of the actinomycetes isolates from their study which showed antimicrobial activities against at least one of the test pathogens, with some isolates having promising broad spectrum antimicrobial activity. Moreover, reports on inhibition of multidrug resistant pathogens by the actinomycetes isolates are of utmost significance for further investigation [7]. These findings on antimicrobial agents from actinomycetes remains hope for proper antimicrobial treatment of infectious diseases which has been challenged by growing multidrug resistance pathogens reported from everywhere attributing high morbidity and mortality $[15,16]$.

Considering the effectiveness and novelty of metabolites from actinomycetes isolates from different parts of the world we too tried to explore the actinomycetes and their antimicrobial potency from the soil of Chitwan district Nepal, as no such reports has been found yet. Chitwan, is plain region of Nepal, rich in flora and fauna influenced by its own topography and climate, where we expect it to harbor unique microbial flora including actinomycetes. Thus, we collected soil samples from different sites viz; from forest, cultivated river side and open waste fields for actinomycetes isolation and screened for their antimicrobial activity. Inhibition of the test pathogens in this study proved their antimicrobial potency of isolates and has opened the way for further investigations regarding the novelty of the metabolites and isolated actinomycetes strain.

\section{Materials and Methods}

This research was carried out in the laboratory of Nepal Polytechnic Institute and Chitwan, for eight months, from September 2015- April 2016. Informed consent was taken from Department of microbiology, Nepal Polytechnic Institute, Chitwan, Nepal.

A. Soil sample collection site

Total 30 soil samples; six from each specified sites (i.e. from the forest, garden, river-side and river side) of Chitwan was collected from the depth of about $11-15 \mathrm{~cm}$.

B. Study site

Sample processing was done in the laboratory Nepal Polytechnic Institute Chitwan, Nepal.

C. Sample collection and processing for isolation and screening of isolates for antimicrobial activity

i) Collection- A total of 30 soil samples (10 gm each) was collected from different sites of Chitwan viz; forest area, cultivable land, river bank and open fields. Soil sample was collected from the depth of $11-15 \mathrm{~cm}$ below the surface and kept in clean plastic bags. Sample thus collected was transported to laboratory, crushed and dried at $50^{\circ} \mathrm{C}$ for about 1 hour.

ii) Isolation and identification of actinomycetes- $1 \mathrm{gm}$ of each sample was mixed with $9 \mathrm{ml}$ of normal saline, vortexed and serially diluted up to $10-5$ in a series of test tubes. Then from selected dilution tube $0.1 \mathrm{ml}$ of the sample was transferred to starch casein agar and spread with sterile glass rod and incubated at $37^{\circ} \mathrm{C}$ for about 7 days. Identification was done by colony morphology, microscopy and biochemical tests. Pure culture was subjected to biochemical test that includes catalase, oxidase, citrate utilization, nitrate reduction, urea hydrolysis, gelatin hydrolysis, acid production from sugar [12].

iii) Selection of pathogenic bacteria- Bacterial pathogens Escherichia coli, Staphylococcus aureus and Salmonella Typhi were taken as test organisms, obtained from Department of Microbiology, Bharatpur Hospital, Chitwan, Nepal.

iv) Primary screening for antagonistic effect- The isolated organism was subjected for antagonistic effect against pathogenic bacteria by single line streak method. In this method, isolated actinomycetes was inoculated in a single streak down the middle of a plate of screening media MHA medium and incubated at $37^{\circ} \mathrm{C}$ for 4 days, then, a single streak of each test organism was added perpendicular to the actinomycetes streak. The plates was incubated for 24 hours at $37^{\circ} \mathrm{C}$ and observed for zone of inhibition [12].

v) Fermentation and extraction of crude antibiotic for secondary screening- On the basis of inhibitory zone size produced in primary screening, those isolates with greater inhibitory capacity was selected for solid state fermentation and crude extract was subjected for antimicrobial activity by agar well diffusion method. Briefly, actinomycetes was selected and grown in a SCB $(200 \mathrm{ml})$ incubated at $37^{\circ} \mathrm{C}$ for 7 days. After 7 days $10 \%$ of the broth was transferred to a flask containing $40 \mathrm{gm}$ wheat grain and $20 \mathrm{ml}$ milk and kept at $37^{\circ} \mathrm{C}$ for 7 days [17]. To concentrate the antimicrobial metabolite, equal volume of ethyl acetate $(200 \mathrm{~mL})$ was added in solid state fermented culture for 1 hour in thermostat water bath shaker at $37^{\circ} \mathrm{C}$ [18]. Then the ethyl acetate containing active metabolite was separated from the solid residue with Whatman No. 1 filter paper. The crude extracts obtained from each isolates was dissolved in ethyl acetate $(76 \mathrm{mg} / \mathrm{mL})$ and used as stock concentration for determination of antimicrobial activity against test pathogens using ethyl acetate as a control. Then, wells ( $6 \mathrm{~mm}$ diameter) were made on MHA using a sterile cork borer. Twenty four hours young culture of pathogenic isolates was swabbed over MHA. Then 6 microliters of crude extract in each well allowed to diffuse then incubated for 24 hours at $37^{\circ} \mathrm{C}$ and observed for zone of inhibition [12].

D. Abbreviations

MHA: Muller Hinton Agar 
SCA: Starch Casein Agar

SCB: Starch Casein Broth

\section{Results}

Out of 30 soil samples collected from different sites of Chitwan, 25 different species of two genera Streptomyce sand Micromonospora from actinomycetes group were identified based on colony characteristics, microscopic observations and biochemical reaction (Table-1 and 2). Of two genera, Streptomyces was predominant $60.0 \% \quad(15 / 25)$ than Micromonospora $40.0 \%(10 / 25)$. Isolation was highest from forest area $(n=9)$, followed by river bank and open fields $(n=6)$ and least from cultivated lands $(n=4)$. Isolation rate of species from Streptomyces genera was higher from soil samples of open waste land $(n=5 / 6)$ and from forest soil $66.6 \%(\mathrm{n}=6 / 9)$. However, two genera i.e. Streptomyces and Micromonospora were isolated in equal numbers from the soil of river bank $(n=3 / 6)$ and cultivable land $(n=2 / 4)$.

All isolates after identification were subjected to primary screening test against three bacterial pathogens (Escherichia coli, Staphylococcus aureusandSalmonellaTyphi) obtained from one of the hospital from Chitwan. On primary screening, 12 out of 25 isolates showed significant inhibition against at least one test pathogen, of which 7 of them were
Streptomycesspp. whereas 5 were Micromonospora spp. (Table-3). Among 12 isolates 6 were isolated from forest area, 3 were from river bank, 2 were from open field and 1 was from cultivated land.

Secondary screening of 12 isolates selected from primary screening revealed 9 isolates showed inhibition against test bacterial pathogens, with inhibition zone size above $8 \mathrm{~mm}$ to $18 \mathrm{~mm}$ diameter. Among those nine isolates 6 of them were Streptomyces spp. whereas 3 of them were Micromonospora spp. and 5 of 9 isolates were from forest soil whereas 3 isolates were from river bank and 1 each from cultivated land and open field. Four isolates (F2, F3, F5 and R1) showed maximum inhibition zone size of diameter against E. coli, Salmonella Typhi and also against $S$. aureus. Three of them were isolated from forest soil and one was from the river bank. Rest of the isolates $(n=5)$ showed inhibition zone size ranging from $5-7 \mathrm{~mm}$ against the test organisms (Table-4). However, in this study, highest zone of inhibition (18mm) was given by the Micromonospora (C1) species isolated against two test pathogens E. coli and Salmonella Typhi. In general, our finding showed isolates are effective against Gram negative pathogens with highest inhibition size of $18 \mathrm{~mm}$, than Gram positive test pathogen (highest zone of inhibition is $14 \mathrm{~mm}$ ).

Table 1. Primary observation for isolation of Actinomycetes.

\begin{tabular}{|c|c|c|c|c|c|c|c|}
\hline S. N. & Sample collection site & $\begin{array}{l}\text { Selection from } \\
\text { Dilution tube }\end{array}$ & $\begin{array}{l}\text { Isolation } \\
\text { technique }\end{array}$ & $\begin{array}{l}\text { Culture media } \\
\text { for isolation }\end{array}$ & $\begin{array}{l}\text { Colony characters of } \\
\text { desired isolates in SCA }\end{array}$ & $\begin{array}{l}\text { Microscopic } \\
\text { observation }\end{array}$ & Inference \\
\hline 3. & $\begin{array}{l}\text { Narayani and Rapti river } \\
\text { bank ( } 6 \text { different sites) } \\
\text { Open field ( } 6 \text { different } \\
\text { sites in between Rapti river } \\
\text { and Narayani river) } \\
\text { Cultivated lands ( } 6 \\
\text { samples from different } \\
\text { cultivated lands) }\end{array}$ & $10^{-2}, 10^{-3}$ and $10^{-5}$ & $\begin{array}{l}\text { Spread plate } \\
\text { method }\end{array}$ & $\begin{array}{l}\text { Starch Casein } \\
\text { Agar (SCA) }\end{array}$ & $\begin{array}{l}\text { White to grey colored } \\
\text { colonies, round with } \\
\text { entire margin and tough } \\
\text { colonies differing with } \\
\text { fungal and bacterial } \\
\text { colonies were selected }\end{array}$ & $\begin{array}{l}\text { Gram positive } \\
\text { reaction with } \\
\text { branching, } \\
\text { filamentous } \\
\text { arrangement of } \\
\text { cells }\end{array}$ & $\begin{array}{l}\text { May be genera of } \\
\text { Actinomycetes }\end{array}$ \\
\hline
\end{tabular}

Table 2. Biochemical tests of the potent isolates showing effective inhibition on primary screening.

\begin{tabular}{|c|c|c|c|c|c|}
\hline Isolates & Catalase/ Oxidase & Gelatin hydrolysis & $\mathrm{H}_{2} \mathrm{~S}$ production & Urea hydrolysis & Nitrate reduction \\
\hline 1 & $+/-$ & + & - & + & + \\
\hline 2 & $+/-$ & + & - & - & + \\
\hline 3 & $+/-$ & + & + & + & + \\
\hline 4 & $+/-$ & - & - & + & - \\
\hline 5 & $+/-$ & + & + & - & - \\
\hline 6 & $+/-$ & - & + & + & + \\
\hline 7 & $+/-$ & + & + & + & + \\
\hline 8 & $+/-$ & - & - & + & - \\
\hline 9 & $+/-$ & + & + & - & + \\
\hline 10 & $+/-$ & + & - & + & + \\
\hline 11 & $+/-$ & + & - & + & - \\
\hline 12 & $+/-$ & + & + & + & + \\
\hline
\end{tabular}

Table 3. Antimicrobial susceptibility of antagonistic actinomycetes against test organisms in primary screening.

\begin{tabular}{lllll}
\hline \multirow{2}{*}{ S. N. } & \multirow{2}{*}{ Isolates label } & Isolated organism & Test organism & Sscherichia coli \\
\cline { 3 - 5 } & & & Salmonella Typhi & + \\
2 & $\mathrm{~F}_{1}$ & Streptomyces & ++ & ++ \\
3 & $\mathrm{~F}_{2}$ & Micromonospora & + & ++ \\
4 & $\mathrm{C}_{1}$ & Micromonospora & ++ & ++ \\
\hline
\end{tabular}




\begin{tabular}{|c|c|c|c|c|c|}
\hline \multirow{2}{*}{ S. N. } & \multirow{2}{*}{ Isolates label } & \multirow{2}{*}{ Isolated organism } & \multicolumn{3}{|l|}{ Test organism } \\
\hline & & & Salmonella Typhi & Escherichia coli & Staphylococcus aureus \\
\hline 5 & $\mathrm{~F}_{3}$ & Streptomyces & ++ & +++ & +++ \\
\hline 6 & $\mathrm{~F}_{4}$ & Streptomyces & ++ & + & + \\
\hline 7 & $\mathrm{~F}_{5}$ & Streptomyces & ++ & +++ & ++ \\
\hline 8 & $\mathrm{R}_{2}$ & Streptomyces & ++ & ++ & ++ \\
\hline 9 & $\mathrm{R}_{3}$ & Micromonospora & ++ & + & + \\
\hline 10 & $\mathrm{O}_{1}$ & Micromonospora & + & + & + \\
\hline 11 & $\mathrm{O}_{2}$ & Streptomyces & + & ++ & ++ \\
\hline 12 & $\mathrm{~F}_{6}$ & Micromonospora & + & + & + \\
\hline 13 & $\mathrm{~F}_{7}$ & Streptomyces & + & - & - \\
\hline 14 & $\mathrm{~F}_{8}$ & Streptomyces & - & - & - \\
\hline 15 & $\mathrm{O}_{3}$ & Streptomyces & - & - & - \\
\hline 16 & $\mathrm{O}_{4}$ & Streptomyces & - & - & - \\
\hline 17 & $\mathrm{R}_{4}$ & Micromonospora & - & - & - \\
\hline 18 & $\mathrm{R}_{5}$ & Micromonospora & - & - & - \\
\hline 19 & $\mathrm{R}_{6}$ & Streptomyces & - & - & - \\
\hline 20 & $\mathrm{O}_{5}$ & Streptomyces & - & - & - \\
\hline 21 & $\mathrm{O}_{6}$ & Streptomyces & - & - & - \\
\hline 22 & $\mathrm{C}_{2}$ & Micromonospora & - & - & - \\
\hline 23 & $\mathrm{C}_{3}$ & Streptomyces & - & - & - \\
\hline 24 & $\mathrm{C}_{4}$ & Streptomyces & - & & - \\
\hline 25 & $\mathrm{~F}_{9}$ & Micromonospora & - & - & - \\
\hline
\end{tabular}

Note: - No inhibition, + show good inhibition, ++ show very good inhibition, and +++ show excellent inhibition; $F$ - indicates isolates from forest soil, Cisolate from cultivable land, $R$ - isolates from river bank, $O$ - isolates from open waste field.

Table 4. Antimicrobial susceptibility of antagonistic actinomycetes against test organisms in secondary screening.

\begin{tabular}{lllll}
\hline \multirow{2}{*}{ Isolates } & \multirow{2}{*}{ Actinomycetes } & \multicolumn{2}{l}{ Zone of inhibition against Test organism (mm) } & Staphylococcus aureus \\
\cline { 3 - 5 } & & Salmonella Typhi & Escherichia coli & $8 \mathrm{~mm}$ \\
\hline $\mathrm{F}_{1}$ & Streptomyces & $8 \mathrm{~mm}$ & $9 \mathrm{~mm}$ & $14 \mathrm{~mm}$ \\
${ }^{*} \mathrm{~F}_{2}$ & Micromonospora & $18 \mathrm{~mm}$ & $18 \mathrm{~mm}$ & $10 \mathrm{~mm}$ \\
${ }^{*} \mathrm{C}_{1}$ & Micromonospora & $8 \mathrm{~mm}$ & $8 \mathrm{~mm}$ & $12 \mathrm{~mm}$ \\
${ }^{*} \mathrm{R}_{1}$ & Streptomyces & $16 \mathrm{~mm}$ & $17 \mathrm{~mm}$ & $10 \mathrm{~mm}$ \\
${ }^{*} \mathrm{~F}_{3}$ & Streptomyces & $17 \mathrm{~mm}$ & $17 \mathrm{~mm}$ & $9 \mathrm{~mm}$ \\
$\mathrm{~F}_{4}$ & Streptomyces & $8 \mathrm{~mm}$ & $8 \mathrm{~mm}$ & $11 \mathrm{~mm}$ \\
${ }^{*} \mathrm{~F}_{5}$ & Streptomyces & $16 \mathrm{~mm}$ & $17 \mathrm{~mm}$ & $9 \mathrm{~mm}$ \\
$\mathrm{R}_{2}$ & Streptomyces & $10 \mathrm{~mm}$ & $9 \mathrm{~mm}$ & $9 \mathrm{~mm}$ \\
$\mathrm{R}_{3}$ & Micromonospora & $10 \mathrm{~mm}$ & $6 \mathrm{~mm}$ & $5 \mathrm{~mm}$ \\
$\mathrm{O}_{1}$ & Micromonospora & $5 \mathrm{~mm}$ & $6 \mathrm{~mm}$ & $5 \mathrm{~mm}$ \\
$\mathrm{O}_{2}$ & Streptomyces & $5 \mathrm{~mm}$ & $5 \mathrm{~mm}$ & $5 \mathrm{~mm}$ \\
$\mathrm{~F}_{6}$ & Micromonospora & $6 \mathrm{~mm}$ & & \\
\hline
\end{tabular}

*Isolates showing maximum inhibition against all test organisms, ${ }^{*}$ isolate showing highest zone of inhibition against test pathogen.

\section{Discussion}

Antibiotics are the most important for the treatment of infectious diseases, increased antibiotic resistant properties of pathogens have increased challenges for effective treatment of infectious diseases [14, 19]. Thus, there has been increasing interest for search of effective antibiotics from soil actinomycetes in diverse ecological niches to fight against increased burden of antibiotic resistant pathogens throughout the globe $[1,4,11,13,20]$. In this study we have isolated and identified 25 actinomycetes strains which were genus Streptomyces and Micromonospora in the ratio 3:2, in other similar studies also these two genera were reported as predominant in which either Micromonospora [21] or Streptomyces isolation was predominant [22]. Of total isolates; $48 \%(12 / 25)$ showed inhibitory activity against one of the test pathogens and this is higher compared to the previous two similar studies reported as $41.5 \%$ by Oskay et al in 2009 in North Cyprus and Ganesam et al in 2017 in
India $(41.5 \%)[23,24]$.

In this study, soil samples from different sites (Forest, River bank, cultivated land and Open field) of Chitwan were collected and processed for actinomycetes isolation. Considering diverse micro-environment of the different sites offering diverse microbial multiplicity soil samples from various sites were collected. Which was inspired by similar previous studies throughout the globe from soil samples from various sites that showed actinomycetes isolation having varied antimicrobial activity $[10,25,26]$. In our study maximum number of isolation was observed from forest area (36.0\%) followed by river bank/open field (24.0\%) and least from cultivable land $(16.0 \%)$. Such discrepancies of isolation rate from different sites might be due to difference in nutritional factors and ecological factors. Highest rate of isolation from forest soil might be because of better organic components present in forest soil that favors for diverse microbes including actinomycetes. Similarly, the least isolation rate from the cultivable land might be because of 
the use of different chemical fertilizers, pesticides etc rendering unfavorable niche to soil actinomycetes.

Primary screening using single streak methods revealed, $48.0 \%(n=12 / 25)$ of isolates were effective inhibitors against test organisms where Streptomyces species were most predominant (58.3\%). This finding is higher $(34.1 \%)$ than previous study done by Gurung et al in 2009 from soil samples of Himalayan region of Nepal and some similar studies in India [10]. However, our result is less than the previous similar research reports $(59.0 \%)$ from India $[20,25,27]$. Different regions with different climate/geography create its own ecology having unique microbial flora with unique characters. From this Chitwan soil we are able to isolate one of the large numbers of actinomycetes isolates showing potent antimicrobial characters during the primary screening test.

On secondary screening $16.0 \%$ of total isolates showed high inhibitory effect against the test pathogens (table-4) which is less than some of the study done elsewhere $[15,27]$ however it is higher that than some of researches carried in Nepal [10] and elsewhere [23, 28]. Inhibition was seen on both Gram positive and Gram negative pathogens which indicate that the produced antibiotic is of broad spectrum nature. This could be possible as actinomycetes might produce more than one antibacterial metabolites that made them effective inhibitor to both Gram positive and Gram negative bacteria [10].

The highest inhibitory effect was seen particularly in Gram negative pathogens (highest inhibition zone of $18 \mathrm{~mm}$ ) than Gram positive bacteria ( $14 \mathrm{~mm}$ highest zone of inhibition). This finding differs from the previous similar research done from the Himalayan region of Nepal [10], which reported, higher inhibitory effect in Gram positive pathogen than in Gram negative. However, one similar study done in Punjab, India reported higher inhibitory effect on Gram negative than Gram positive which is consistent with our study [15].

Our finding on effective zone of inhibition size $(8-18 \mathrm{~mm})$ on secondary screening of isolates against test pathogens is comparable with most of the previous similar studies against different test pathogens. Vijayakumar et al. from India reported extract of Streptomyces sp. produced highest zone of inhibition of $23 \mathrm{~mm}$ against $P$. vulgaris and lowest zone of inhibition of $15 \mathrm{~mm}$ against $S$. aureus [29] Saravanakumar et al. from Tamil Nadu, India also reported that intra cellular methanol extract of Actinobacterium showed maximum zone of inhibition of $21 \mathrm{~mm}$ against $P$. vulgaris and lowest zone inhibition of $15 \mathrm{~mm}$ against $B$. subtilis [30]. Similarly, a research work carried out by Pathalam et al in India reported maximum zone of inhibition of $25 \mathrm{~mm}$ against $B$. subtilis [23]. Such differences in the results might be due the variation in the strains and types of actinomyctetes from the different habitats.

\section{Conclusion}

In this study four broad-spectrum antibiotic producers $F_{2}$, $\mathrm{F}_{3}, \mathrm{~F}_{5}$ and $\mathrm{R}_{1}$ were isolated and identified from plain region of Nepal, Chitwan. Isolates might belong to a distinct actinomycetes strain with a promising candidate for discovering novel and potent antibiotic. Because of resource limitations, we were unable to use molecular level study to confirm our results. Further, larger numbers of samples would have produced more significant results.

\section{Acknowledgements}

The authors are grateful to Nepal Academy of Science and Technology (NAST) for providing competitive research grants to carry out this study. The authors would also like to thank the students of Nepal Polytechnic Institute and technical staffs for their assistance during this research work.

\section{References}

[1] Agarawal VP "Micorbial Biodiversity of Khumbu region: Study of antibiotic activity of Actinomycetes", http://www.evk2cnr.org/files/PAgrawal01.pdf.

[2] Magarvey NA, Keller JM, Bernanetal V. Isolation and characterization of novel marine derived Actinomycetes taxa rich in bioactive metabolites. Applied and Environmental Microbiol. 2004; 70: 7520-7529.

[3] Okami Y, Hotta K. Search and discovery of new antibiotics", In: Actinomycetes in biotechnology (Eds. M. Good Fellow, S. T. Williams and M. Mordarski). Academic press, London1988: 37-67.

[4] Sathi ZS, Md AA Rahman, Gafur MA. Identification and in vitro anti-microbial activity of a compound isolated from Streptomyces species. Pakistan J Biol Sci. 2001; 4 (12): 15231525.

[5] Zhao H, Parry RL, Ellis DI, Griffith GW, Goodacre R. The rapid differentiations of Streptomyces using fourier transform infrared spectroscopy. Vibrat Spectr. 2006; 40: 213-218.

[6] Valli S, Suvathi SS, Aysha OS, Nirmala P, Vinoth P, Reena A. Antimicrobial potential of Actinomycetes species isolated from marine environment. Asian Pac J Trop Biomed. 2012; 6: 469-473.

[7] Nathan AM, Jessica MK, Valerie B, Martin D, David HS. Isolation and Characterization of Novel Marine-Derived Actinomycete Taxa Rich in Bioactive Metabolites. Appl. Environ. Microbiol. 2004; 70 (12): 7520-7529.

[8] Sengupta S, Pramanik A, Ghosh A, Bhattacharyya M. Antimicrobial activities of actinomycetes isolated from unexplored regions of Sundarbans mangrove ecosystem. BMC Microbiol. 2015; 15: 170.

[9] Rahman A, Islam MZ, Islam AUI. Antibacterial Activities of Actinomycete Isolates Collected from Soils of Rajshahi, Bangladesh. Biotechnol Res Int'l. 2011 (2011): 1-6.

[10] Gurung TD, Sherpa C, Agrawal VP, Lekhak B. Isolation and characterization of antibacterial Actinomycetes from soil samples of Kalapatthar, Mount Everest Region. Nepal J Sci Technol. 2009; 10: 173-182.

[11] Bizuye A, Moges F, Andualem B. Isolation and screening of antibiotic producing Actinomycetes from soils in Gondar town, North West Ethiopia. Asian Pac J Trop Dis 2013; 3 (5): 375-381. 
[12] Panwar D, Vipin SK. Antagonistic activity of soil actinomycetes against common Human pathogens. Int J Pharm Bio Sci, 2012; 4: 500-506.

[13] Attimarad SL, Ediga GN, Karigar AA, Karadi R, Chandrashekhar N, Shivanna C. Screening, isolation and purification of antibacterial agents from marine Actinomycetes. Int'l Current Pharmaceut J. 2012; 1 (12): 394 402 .

[14] Ceylan O, Okmen G, Ugur A. Isolation of soil Streptomyces as source antibiotics active against antibiotic-resistant bacteria. Eur Asia J Biol Sci. 2008; 2 (9): 73-82.

[15] Rana S, Salam MD. Antimicrobial Potential of Actinomycetes Isolated from Soil Samples of Punjab, India. J Microbiol Exp. 2014; 1 (2): 00010.

[16] Padalkar RR, Peshwe SA. Isolation and characterization of new anti-MRSA producing Actinomycete. Indian J App Res. 2013; 3 (6): 433-436.

[17] Thenmozhi M, Kannabiran K. Studies on isolation, classification and phylogenetic characterization of novel antifungal Streptomyces sp. VITSTK7 in India. Curr Res J Biol Sci. 2010; 2 (5): 306-312.

[18] Selvameenal L, Radhakrishnan M, Balagurunathan R. Antibiotic pigment from desert soil actinomycetes; biological activity, purification and chemical screening. Indian J Pharm Sci. 2009; 71 (5): 499-504.

[19] Alanis AJ. Resistance to antibiotics: are we in the postantibiotic era. Archives of Medical Research. 2005; 36 (6): 697-705, 2005.

[20] Abo-Shadi M. Abd. AR, Sidkey NM, Al-Mutrafy AM. Antimicrobial agent producing microbes from some soils rhizosphere. J Am Sci, 2010; 6 (10): 915-925.

[21] Khandan ND, Janardhana GR. Diversity and Antimicrobial activities of Actinomycetes isolated from soil samples of Kodagu, Karnataka State (India). Int'l J Microbiol Res. 2013; 5: 404-409.
[22] Gopala krishnan S, Sunder J, Sasidharan V, Subramanian SE. Antibacterial activity of actinobacteria isolated from mangroves of Andaman and Nicobar Islands, India. Adv. Anim. Vet. Sci. 2016; 5: 230-236.

[23] Pathalam G, Appadurai DR, Rajendran HAD, Munusamy RG, Michael GP, Naif AAD, Savarimuthu I. Antimicrobial activity of some actinomycetes from Western Ghats of Tamil Nadu, India. Alexandria Journal of Medicine. 2017; 53: 101-110.

[24] Oskay M. Antifungal and antibacterial compounds from Streptomyces strains. African Journal of Biotechnology. 2009; 8 (13): 3007-3017.

[25] Kumar N, Singh RK, Mishra SK, Singh AK, Pachouri UC. Isolation and screening of soil Actinomycetes as source of antibiotics active against bacteria. Int'l $\mathrm{J}$ of MicrobiolRes. 2010; 2 (2): 12-16.

[26] Kumari M, Myagmarjav BE, Prasad B, Choudhary M. Identification and Characterization of antibiotic-producing Actinomycetes isolates. Amer J of Microbiol. 2013; 4 (1): 2431.

[27] Emelda EJ, Vijayalakshmi N, Santhanakrishnan T. Antimicrobial activity of antibiotic producing Streptomyces macrospores. J of Pharma and Biol Sci. 2012; 2 (3): 20-23.

[28] Jeffrey LSH. Isolation, characterization and identification of actinomycetes from agriculture soils at Semongok, Sarawak. Afr J of Biotech. 2008; 7 (20): 3697-3702.

[29] Vijayakumar R, Panneer SK, Muthukumar C, Thajuddin A, Panneerselvam A, Saravanamuthu R. Antimicrobial potentiality of a halophilic strain of Streptomyces sp. VPTSA18 isolated from saltpan environment of Vedaranyam, India. Ann Microbiol. 2012; 62: 1039-47.

[30] Saravanakumar P, Preetjam Raj JP, Duraipandiyan V, Ignacimuthu S. Antibacterial activity of some actinomycetes from Tamil Nadu, India. Asian Pac J Trop Biomed. 2012; 2:936-46. 